DoI: http://dx.doi.org/10.11157/sites-vol13issiid333

- ARTICLE -

\title{
COSMOPOLITAN METHODS AND RECRUITING THE URBAN STRANGER IN AOTEAROA NEW ZEALAND
}

\author{
Molly George ${ }^{1}$
}

\begin{abstract}
This article emerges from the fieldwork experiences and methodological issues that arose while conducting fieldwork with older New Zealanders in two urban settings of diversity and multiculturalism in Aotearoa New Zealand. Some of the encountered methodological complexities are discussed, including the inherent complications around categorisation and ethnicity when approaching the urban setting as the ethnographic field, particularly in a New Zealand context. I argue that serendipitous, fleeting interactions between ethnographer and those encountered in urban fields do not afford individuals the respectful time and space necessary to discuss matters of identity, such as ethnicity. I suggest, then, that the urban anthropologist is a peripheral stranger among other urban strangers and must employ an ethical, cosmopolitan detachment by refraining from ready categorisations in the urban field. With this discussion of cosmopolitanism-as-method, I thus present Aotearoa New Zealand as sitting at the periphery of an 'anthropological gaze' that still prioritises ethnic groupings.
\end{abstract}

\section{INTRODUCTION}

This article emerges from the fieldwork experiences and methodological issues that arose while conducting fieldwork with older New Zealanders in two urban settings of diversity and multiculturalism in Aotearoa New Zealand. This project explored some older New Zealanders' experiences and understandings of the significant increase and diversification of immigration into New Zealand that has occurred during their lifetimes. While undertaking fieldwork, I inadvertently landed smack in the middle of several 'hot topics' in contemporary discussions of ethnographic methods. This article thus weaves together a discussion of some of these methodological complexities I encountered, including the inherent complications around categorisation and ethnicity when approaching the urban setting as the ethnographic field, particularly in a New 


\section{Zealand context.}

I argue that serendipitous moments are at the heart of ethnography and must be retained in urban settings; however, fleeting interactions between ethnographer and those encountered in urban fields do not afford individuals the respectful time and space necessary to discuss matters of identity, such as ethnicity, of their own volition. In this article, I present the urban anthropologist as a peripheral stranger who employs an ethical, cosmopolitan detachment by refraining from ready categorisations when interacting among other urban strangers in settings of diversity. Furthermore, as demonstrated by an international grant reviewer's lack of understanding of 'New Zealander' as a research participant category based on nationality and citizenship, I present Aotearoa New Zealand as sitting at the periphery of an 'anthropological gaze' that instead still prioritises ethnic groupings.

\section{THE NEW ZEALAND CONTEXT}

In this section, I briefly explain New Zealand's unique socio-cultural, political and historical context as this setting presents a fascinating backdrop for studying contemporary multiculturalism as a daily lived reality. Understanding the specific New Zealand context is also essential to the discussion of cosmopolitanism as method that will be presented in this article. As a former colony and settler society with a bicultural framework, ethnic and cultural diversity are hardly new to New Zealand. However, New Zealand's population history clearly has been dominated by two groups - Māori, the Tangata Whenua or Indigenous population who settled in New Zealand approximately 800 years before European arrival (Wilmshurst et al. 2008) and European settlers (representing the diversity inherent in this grouping but primarily British), who began settling in New Zealand approximately 180 years ago (Smith 2008). The process of establishing a political and social partnership between Māori and the British Crown began in 1840 with the signing of the Treaty of Waitangi and this process continues today (MacPherson 2005). Until the late 1960s, the structure of this bicultural framework, and continued close political and economic ties with Britain, acted to maintain a population consisting of Māori and a non-indigenous population that was over 96 per cent British settlers and their descendants. This high percentage of British settlers made New Zealand the most homogenous of the former British colonies (Ip 2003; McMillan 2004; Spoonley and Bedford 2012).

New Zealand's immigration policy through World War II has been referred to as 'whiter than white' as it heavily prioritised British immigrations and ac- 
tively discouraged non-European immigrants, particularly those from Asia (Brooking and Rabel 1995; Ward and Lin 2005). In the 1950s, for example, as New Zealand (begrudgingly) looked beyond British settlers to fill its labour needs, an agreement was made with the Netherlands to accept a large number of Dutch migrants into New Zealand. The Dutch were considered ideal due to their whiteness and their high likelihood of assimilating, even being called 'honorary Britishers' (Lochore 1951; Roggeveen 1996). Also during the 1950s, immigrants were sought from the neighbouring Pacific Islands to fill New Zealand's booming post-war economy. However, during this time and into the 1960s, overseas born Pacific Islanders and Asians together still equalled less than one per cent of the population, with foreign-born European residents not of British stock equalling less than two per cent (Brooking and Rabel 1995).

Over the next several decades, with a few exceptions to its 'white New Zealand' immigration policy, New Zealand's ethnic diversity remained minimal, with careful preference given to immigrants from Australia, North America, Western Europe and of course, first and foremost, the United Kingdom. In 1986, however, immigration policies were restructured in tandem with economic restructuring, resulting in large numbers of various Asian and other non-European immigrants coming to New Zealand. Done without Māori consultation and thus arguably in violation of the Treaty of Waitangi (Hill 2010; Ip 2003), the implementation of the 1987 Immigration Act and of a 'point system' in 1991 effectively abolished traditional source-country preferences and instead emphasised skills, language, qualifications, adaptability and capacity to settle (Zodgekar 2005).

Though the change was economically and politically motivated, largely in response to the upward mobility of East and Southeast Asian states and their importance to New Zealand as trading partners (Palat 1996), the social ramifications have been substantial. In just the ten years after the immigration policy changes took place, Asian immigration increased 240 per cent (Statistics New Zealand 2014; Ward and Masgoret 2008). A Statistics New Zealand report explained that in 2013 overseas-born residents from 'Asia' collectively equalled $31.6 \%$ of the overseas born population; Asia thereby overtook the United Kingdom and Ireland as the most common birthplace for overseas-born residents (Statistics New Zealand 2014). The report also contained a comparison of the birthplaces of the overseas population between 2013 and 1961; the percentage of New Zealand's overseas-born population from the United Kingdom dropped from 45.7 to 21.5 per cent in those fifty-two years. Furthermore, due largely (though not entirely) to changes in immigration, New Zealand, like most developed nations (Castles and Miller 2009), now has a youth cohort 
with a far greater degree of ethnic diversity than its older generations (Ministry of Social Development 2010).

The story of immigration in New Zealand, especially since World War II, is one of 'increasing cultural diversity of New Zealand at the same time as the country has explored biculturalism' (Spoonley and Bedford 2012, 26). These demographic shifts have brought New Zealand national identity into question (Hill 2010) and introduced multiculturalism into a nation still striving for a meaningful, working biculturalism (Marotta 2000). Unexpected social consequences have included the new formation of ethnic minorities outside of the Māori and British settler framework (Spoonley 2011). Within this context, the aim of my own research was to explore how some older New Zealanders, whose lives have encompassed the development of globalisation, transnationalism and the growth of multiculturalism in New Zealand, have experienced the increasing socio-cultural diversity around them.

\section{EXPLORING OLDER NEW ZEALANDERS' EXPERIENCES OF INCREASING DIVERSITY}

This project emerged from my general interest in the anthropology of ageing and, specifically, from a desire to locate older folks in settings of diversity and difference. To explore older New Zealanders' perceptions and experiences of 'accelerated cultural change' (Perkinson and Solimeo 2013, 105) related to globalisation, immigration and population diversification that has taken place since the 1987 Immigration Act, I sought out New Zealanders over the age of 65 in two of New Zealand's main cities: Auckland and Dunedin. Auckland is a high-density, ethnically diverse city and home to one-third of the national population and two-thirds of all immigrants into New Zealand (Friesen 2010). Auckland, a city of 1.2 million people, fits the definition of a super-diverse city (Vertovec 2010) on par with London or Los Angeles (Spoonley 2011), with ethnic enclaves including a proposed 'China Town' (NZPA 2011). Dunedin, on the other hand, represents one of several smaller provincial cities which act as a hub for the more sparsely populated, rural or semi-rural provinces with Pākehā (white/European) majorities. A city of 120,000, Dunedin has a proportionally far smaller, more dispersed and less visible migrant population. I did not approach these two locales in a comparative manner; rather, they were chosen to collectively create a partial account of lived multiculturalism and everyday cosmopolitanism in urban and semi-urban New Zealand.

In both locales, data was collected through the methods of participant observation, thematic analysis of formal interviews and some use of photographs and 
video. My fieldwork included twenty-three interviews with New Zealanders over the age of 65 (fourteen in Auckland, nine in Dunedin) as well as substantial participant observation. This participant observation included engaging in short, casual conversations with older people on public transport, attending a kaumatua morning at a marae, doing Zumba with a seniors' group in a community centre, attending seniors' group meetings, 'hanging out' in a Returned Service Association (RSA) clubroom, volunteering with an ESOL group, observing and interacting with older people in daily settings of diversity such as public markets, supermarkets, pharmacies and more. All participant observation was diligently recorded as copious fieldnotes which were coded and analysed as primary data alongside the formal interviews.

PROBLEMITISING ETHNIC CATEGORIES IN ANTHROPOLOGICAL FIELDWORK: THE USE OF 'NEW ZEALANDER'

When approaching Auckland and Dunedin in this manner, and seeking out New Zealanders over the age of 65 to speak with, the use of different labels and categories was an immediate consideration and issue. For example, 'older' is certainly a problematic categorical label. To gather some perceptions of New Zealand's demographic change over time, I aimed to speak with those whose memories encompassed at least the last fifty years. I settled on an age-based category of ' $65+$ ' for two reasons. First, Statistics New Zealand keeps data on this 'segment' of the population, allowing access to statistics in tandem with my own empirical data. Second, 65 is the current age at which New Zealanders are eligible for the public pension, making this a familiar, common categorisation. But this category is problematic. For example, it does not account for the diversity within the category, it is largely fabricated by researchers and policy makers, and furthermore, as people live longer, the category is becoming arbitrary as there are significant differences between the life stories, memories, current life situations, health, mobility and more for a 65 year old versus a 95 year old.

Another category proved to be the most complicated and problematic, however; that of 'New Zealander'. In New Zealand's post-colonial, bicultural paradigm, this category of 'New Zealander' is fraught with socio-political tension (see Bartley and Spoonley 2005; Callister 2004; Spoonley and Bedford 2012) which hums along as a constant backdrop to conversations of national identity, biculturalism and multiculturalism. Among other places, the debate around what constitutes a 'New Zealander' has manifested in census data. As an increasing number of people are answering 'New Zealander' in response to questions about ethnicity in official surveys, the fundamental question of whether or not 'New Zealander' can be considered an ethnicity has been raised. In 
the 2006 census, 11.1 per cent of respondents answered 'New Zealander' alone or in combination with another ethnic group (Kukutai and Didham 2009). In the 1991, 1996 and 2001 censuses, those who wrote in 'New Zealander' for ethnicity were subsequently regrouped by Statistics New Zealand as 'New Zealand European' in spite of significant evidence that those answering 'New Zealander' were also of Māori, Pacific Island and other ethnic backgrounds (Callister 2004). In 2004, Statistics New Zealand recommended that this policy of regrouping be stopped (Callister 2004) and recognised the issue of New Zealander-as-ethnic-identity as a priority (Kukutai and Didham 2009).

It is argued that a category of 'New Zealander' allows those of, for example, European or Asian ancestry, who hold no affinity with Europe or Asia, to identify as a second 'indigenous' group to New Zealand. Also, some people with complicated mixtures of cultural and ancestral backgrounds use the category of 'New Zealander' as a new amalgamation (Callister 2004). However, even though it is known that some people of Māori ancestry write in 'New Zealander' for ethnicity (Callister 2004), the category of 'New Zealander' as ethnicity is considered to be harmful to Māori for several reasons including: it creates problems for Māori/non-Māori comparisons; it does not sit well within a concept of the Treaty of Waitangi as being between two distinct peoples; and it is a step toward the creation of a second indigenous group, undermining Māori's status of indigeneity within New Zealand (Callister 2004; Statistics New Zealand 2004).

Beyond these domestic discussions, the category of 'New Zealander' is a source of some international misunderstanding. Here I turn to the main event that led to my own analysis of my use of 'New Zealander' in my urban-based anthropological research. For the purposes of my research, my intention was to use the term as an inclusive nationality, not indicative of ethnicity, though I certainly recognised the flaws and complications in doing so. However, international misunderstanding of the use of 'New Zealander' as a nationality-based category and not indicative of ethnicity was clearly demonstrated by a response from an overseas grant application reviewer. When I was about a quarter of the way through my fieldwork, the reviewer proposed that my research design was inherently and fatally flawed because s/he assumed that by 'New Zealander' I was referring to a specific ethnic category of white/European background. Thus, s/he further assumed that I was therefore was not including Māori (or any other ethnicity) in my category of 'older New Zealander'.

In the shadow of this harsh review, I considered narrowing down my focus to 'older, Pākehā New Zealanders'. Doing so would have had certain benefits such 
as avoiding misinterpretation and controversy over who was being included or excluded and allowing me to refute any possible accusations of 'studying down' (Hannerz 2006) as I myself can (contestably) be considered 'Pākehā. Thus, I almost succumbed to what Martin Tolich (2002) has called 'Pākehā Paralysis' - a state of paralysis that many postgraduate Pākehā researchers in New Zealand find themselves in, feeling they have 'no place researching Māori' (Tolich 2002, 165). The history of poor treatment and exploitation of Mãori in research in New Zealand is well documented (Bishop 1998; Smith 1999; Walker 1985). Speaking as an Indigenous New Zealand researcher, Linda Tuhiwai Smith (1999) wrote that anthropologists in the past have approached Indigenous New Zealanders with 'innate superiority', stealing knowledge that benefits only the researchers: 'They Came, They Saw, They Named, They Claimed' (Smith 1999, 56,80 ). This complicated history in New Zealand must absolutely be recognised; research about Māori by non-Māori is complex and conceals unequal power dynamics harmful to Māori (Smith 1999). According to Tolich (2002), many Pākehā researchers, aware of the historical exploitation and resulting resistance to research 'on Māori' recognise the issue as a 'political minefield' and go so far as to exclude, and coach their students to exclude, Mãori participants from their research (Tolich 2002, 167). However, Tolich (2002) argues that when research is on or about the general population of New Zealand, the exclusion of Māori participants violates the ethical obligation to avoid doing harm. It presents a violation of the Treaty of Waitangi as this act then also excludes Māori from any possible benefits of that research, research that is often largely state-funded (Tolich 2002). This last point was echoed by three Māori academics I consulted in person after receiving the grant reviewer's comments. All recognised and advised me about the complexity of the social, political and historical situation of exploitative research on Māori; however, all three also echoed Tolich by suggesting that avoiding Māori when conducting research on the general population of New Zealand could, alternatively, be considered unethical, with one possible alternative interpretation of the situation being that I actually had a duty to include Māori in my research category of older 'New Zealanders'.

After ample discussion and consideration, I was buoyed to stay committed to the use of 'New Zealander' as an inclusive category based on nationality or citizenship, rather than ethnicity in the context of my research topic and approach. However, the pressure to specify ethnic categories for an international anthropological audience, and the desire to avoid future confusion about my use of 'New Zealander', led me to toy with the idea of pursuing a purposive sample that mimicked the ethnic breakdown of the $65+$ segment of New Zealand's population. Statistically, this age category's ethnic makeup looks like this: 
91\% European, 5\% Māori, 4\% Pacific Island and 2\% Asian (Ministry of Social Development 2010). Roughly mimicking these statistics in my own sample seemed to offer an enticingly 'neat and tidy' response to questions and doubt around the ambiguity of 'New Zealander'. However, as I will describe in the next section, my fieldwork had an intentionally ad hoc approach as I attempted to approach 'the city' and its diverse inhabitants as 'the field'. This meant my fieldwork included constant, ephemeral, anonymous interactions inherent in city life. The brief time during which I had a proportional sample in mind proved to be a stressful fieldwork disaster.

\section{APPROACHING THE CITY AS FIELD AND FINDING PARTICIPANTS}

Before describing my own approach to the urban field and how this shaped my data, I will first briefly summarise a few of the pertinent points within current, broader discussions of urban anthropological fieldwork. 'Traditional' anthropological fieldwork has largely fit certain criteria: compartmentalised and 'away', rural, exotic, solitary and long in duration. This paradigm of anthropological fieldwork is increasingly under scrutiny by those who acknowledge this rendering is not even 'a serviceable fiction' for many contemporary ethnographers (Amit 2000, 2) including those who write about fieldwork experiences 'at home' (Caputo 2000; D'Alisera 2004; Dyck 2000), accompanied by family (Drozdzewski and Robinson 2015; Farrelly, Stewart-Withers, and Dombrowski 2014; Flinn, Marshall, and Armstrong 1998; Frohlick 2002) or undertaken in urban areas (Foster and Kemper 2010; Gottlieb 2012; Hannerz 2006; Radice 2000) . Nonetheless, traditional notions of what constitutes 'authentic fieldwork' led D'Alisera (2004), for example, to find it rather disconcerting when her fieldwork had to be changed from rural Sierra Leone to studying Sierra Leoneans in Washington D.C., for political, logistical and safety reasons. Her new fieldsite of Washington DC was not only close to home, it was a city. Upon driving into the city, she questioned herself and her research aim, 'This isn't even rural. This isn't really fieldwork (D’Alisera 2004, 20). Similarly, Gmelch and Gmelch (2009) wrote about how their fieldwork students who conducted fieldwork in the Australian city of Hobart felt they were not doing 'real ethnography' in comparison to the remote, isolated Malinowski experience they had been taught in the classroom. Anthropologists are still presumed to be 'sojourners of the between' (Stoller 2012) - one moves from 'home' to go 'there' with 'there' typically involving remote or rural areas. The nearby and 'the city' - for ethnographers who often normally reside in cities - are assumed not to possess the essential alchemy or tension of a site that is culturally, socially and spatially distant, but is then rendered familiar by the ethnographer (Amit 2000). 
Additionally, some lingering uncertainty about the authenticity of urban ethnography lies simply in the difficulty of approaching the modern city as the field. Traditional methods do not always apply and urban ethnographic methods are rarely taught (Pardo and Prato 2012). Simply knowing where to start seems to be the first challenge (Foster and Kemper 2010); Alma Gottlieb wrote that after several months in her field of Lisbon, she was not even sure 'if or when I'd actually started fieldwork' (Gottlieb 2012, 93). To make the city more approachable through traditional ethnographic methods, anthropologists largely study city life through the lens of one neighbourhood or one subculture within the broader city (Foster and Kemper 2010; Radice 2011). But Radice (2011), who conducted fieldwork in Montreal, wrote that the problem with this approach is its implication and assumption of the city as an urban village, a collective of parts, rather than examining 'the city at the ontological level at which it exists' (Huyssen 2008; Radice 2000, 17). Radice questioned, 'How can we capture the city as a city, at the level where its urban qualities - density, heterogeneity and mobility of population - really matter?' (Radice 2011, 13). In breaking the city down into its parts, much of what is truly urban can still be missed. Some anthropologists have focused instead on specific public places, like a market or plaza - grasping some of the interactive, relational nature between diverse people.

Finding participants can be the next obvious challenge of urban fieldwork (Foster and Kemper 2010). D'Alisera expressed this conundrum in her early weeks and months of fieldwork in Washington DC: 'I constantly wondered where and how to begin. I was not even sure where 'the field' was'. And about her potential informants, she questioned, 'But where would I find them, and how?' (D'Alisera 2004, 25). Anthropologists' traditional strategy of living amongst their subjects of study cannot apply when members of a group being studied may be dispersed across a city, possibly not even knowing each other (Caldwell 2010; Foster and Kemper 2010). Anthropologists George and Sharon Gmelch (2009) have run a field school for their social anthropology students for over thirty years and recently the location was changed from various villages in Barbados to the Australian city of Hobart. Their fieldwork students in Barbados villages left their homestays in the morning and encountered potential informants. Nearly all residents were aware of the students' presence. When the Hobart-based students left their suburban homestays, they seldom encountered anyone and struggled to approach strangers. After two weeks in Hobart, a student wrote in her fieldnotes, 'I'm still not sure how to find informants.' Gmelch and Gmelch wrote, 'No student in Barbados ever reported that problem' (Gmelch and Gmelch 2009, 297). 
For the students in Hobart, informants were often found through contacts and connections, and eventually through pre-arranged internships with a certain group, club or service. Oftentimes interviews were set up by phone or email with a person that the student ethnographer had never seen before and would never see again. Student fieldwork in an urban setting showed a heavier reliance on formal interviews and less opportunity to see their subjects in their natural surroundings, which also meant fewer fieldnotes (Gmelch and Gmelch 2009). This sort of urban fieldwork emphasis on interviews with less time spent in classic participant observation is what Hannerz refers to as 'anthropology by appointment' as opposed to 'anthropology by immersion' (Hannerz 2006, 34). One criticism of this heavy focus on scheduled interviews is the gap between knowing what participants say and knowing if that is really how things play out in unobserved life (Gmelch and Gmelch 2009). In urban settings, a heavier reliance on interviews may often be necessary as getting a sense of people as they move from one place to another can be, at the very least, tricky. But an anthropologist moving as a peripheral stranger among strangers, where knowledge of the Other remains superficial, should also be recognised as participating in the reality of urban, anonymous lives in motion.

\section{APPROACHING AUCKLAND AND DUNEDIN}

In trying to avoid the pitfalls of an urban ethnography which relies heavily on isolated interviews suspended in space, decontextualised from the person's daily life and habits, I tried to approach my fields of Auckland and Dunedin somewhat like a village - wandering around, observing daily life, striking up conversations. In her recent ethnography, Wessendorf (2014) described an approach to Hackney, London that was very similar to my own approach to the field. In viewing inter-ethnic interactions in the area, Wessendorf attended knitting groups, an IT class, a youth club on a housing estate, a parents' morning coffee, and dropped into a centre for migrants. She carried out participant observation in public spaces such as shops, parks and a market where she 'hung out by one of its curry stalls, observing traders' and customers' interactions' and in playgrounds where she chatted with parents (Wessendorf 2014, 16). She wrote that her fieldwork draws upon a 'myriad of encounters, conversations, interviews and observations' and included meeting 'anyone and everyone' she could without simplifying and isolating categorical units (Wessendorf 2014, 18).

From my own fieldwork, I can provide an example of this approach. I had heard from a colleague that the neighbourhood of Papatoetoe, Auckland had experienced a rapid and substantial growth in population diversity in the last 
two decades. I found that there was an Age Concern office in this area and that became my destination for the day. In the morning, I took the train from central Auckland to Papatoetoe. Within a small stretch of a couple of blocks, there was the office for the Manukau Urban Māori Authority, a fruit and veggie shop seemingly catering to an Asian clientele, a large retail shop selling saris and a church with service times for people of various Pacific Island nations. I spoke with a few people in these offices and shops and then easily found a café that seemed to have an older clientele. I sat for a while, watching interactions and having some informal conversations with those who could be classified as 'older New Zealanders'. I noticed the Returned Service Association (RSA) chapter across the street and wandered in. The bartender heard my story, took an information sheet, and made an unexpected announcement about me and my research to the ten or so older folks chatting over their cups of tea or pints of beer. She quietly told me that a lot of these people would appreciate some conversation and she welcomed me anytime. I spent the rest of the day at the Papatoetoe RSA, and then two more days, speaking casually with approximately ten older New Zealanders. This also led to three formal interviews subsequently arranged in individual homes.

In this way, I attempted to avoid Hannerz's 'pitfalls of anthropology by appointment' (Hannerz 2006,34). I aimed to observe city inhabitants in their everyday surroundings, going about their daily lives, having conversations on-the-go, reflecting the reality of many urban encounters. I took copious fieldnotes which were coded and analysed alongside the formal interview transcripts. Though an article about my research featured in a Dunedin Age Concern newsletter and lead to several interviews, I never advertised for participants. Particularly in Auckland, I met them, organically, if you will, on the ground. This style meant that I first observed and found my participants in their surroundings, interacted with them there (if briefly), and then met some of them again for a formal interview. In approaching the city this way, I was able to include some good, old-fashioned participant observation. Ingold, in his plea to distinguish participant observation from the overused term, 'ethnography', writes that participant observation is 'a practice' at the centre of anthropology, that requires us 'to attend to what others are doing or saying and to what is going on around and about; to follow along where others go... whatever this might entail' (Ingold 2014, 389). This approach is open to the kind of serendipitous discovery that is the hallmark of so much fieldwork (Monaghan and Just 2000) such as when the Indian migrant owner of the Auckland hostel where I was staying walked me across the street to a state pensioner flat to meet the elderly New Zealander who tutors the hostel-owner's children, or when I met a Tongan immigrant behind a Dunedin antique shop who talked at length 
about the dynamics between Tongan immigrant caregivers and the elderly (largely Pākehā) New Zealanders that they care for. In this way, I aimed to maintain the enduring key to ethnographic success: being there, available to observe, available to follow up, available to take advantage of the chance event (Monaghan and Just 2000) in 'equal measures of serendipity and deliberate enterprise' (Amit 2000, 16).

Like D'Alisera (2004) and Gmelch and Gmelch (2009) both noted, I found that approaching the city as the field can require a significant amount of time spent in transit, moving between various members of the 'community' being studied. I deliberately avoided renting a car in Auckland and instead considered the whole process of getting to and from certain areas or interviewees to be 'fieldwork'. Locals bemoan that the public transit system does not facilitate getting anywhere quickly, but I would stretch the journey out on purpose; while waiting for a connecting bus, I would wander into a supermarket, library or community centre. Another example here will illustrate my use of the spare time created by my use of public transit and further solidify the style of my approach to Auckland and Dunedin as urban fields.

I was going to meet with an interviewee in a relatively quiet inner-suburb of Auckland. I sat at the back of the bus and watched interactions between passengers and observed the areas we passed through. Due to the limited bus schedule, I arrived in the interviewee's neighbourhood nearly an hour before our scheduled meeting and wandered around the neighbourhood. From the business signs written in Korean and Chinese, it became obvious that this area had a significant Korean and Chinese population. I began to pay attention to the few people driving slowly along the residential streets. Many appeared to be older Pākehā New Zealanders and many also appeared to be people of Asian ethnicities. Happening upon the Community Centre, I wandered in. What seemed to be a young Korean mother's group was just leaving the building. I looked at the content of the information on the notice boards: English Language Partners, wearable emergency alarms, a driving service for elderly, a companionship program for elderly, and settlement services for new migrants. I knocked on the door of the office and two women greeted me. One, an older woman, was suspicious when I mentioned that I was doing research, but reluctantly talked with me. I asked if I was correct in my observations that this neighbourhood seemed to have a lot of older New Zealanders and Asian immigrants. She perked up at my specific but accurate observation and confirmed that the area consists mainly of both these categories. She told me that she belonged to a choir group and an orchestra group and, now that she thought of it, both were made up precisely of older New Zealanders and Asian immigrants. 
The average age of the group was rising as few young New Zealanders were joining the choir or orchestra, but then the neighbourhood began to fill with Asian immigrants, who, she felt, commonly value music and often became keen new members of both groups. In her words, if I were to come to a gathering or a show, I would see 'an audience of grey haired New Zealanders and Asians'. In her opinion, the boost and revival that the Asian immigrants offered to these musical groups was appreciated and represented a positive realm of interaction among the local, older New Zealanders and new immigrants.

This kind of thing happened again and again - in supermarkets or pharmacies where I would either just observe or strike up casual conversations with employees or shoppers. Furthermore, one person's passing insight would help me follow up on relevant 'arenas of interaction', events and phenomena. In the case of the older woman I spoke with at the community centre, her insight about 'Asians' and 'older New Zealanders' in her choir and orchestra inspired me to keep an eye on small, regional music groups as another area where older New Zealanders and immigrants might interact. This in turn led to fieldwork at such local music groups, which then led to another formal follow-up interview in someone's home. With this approach, particularly in Auckland, I had the feeling of wandering about the city, successfully plucking a person here and a person there, out of the hum of the city and their own daily life for a chat and, with a few, a longer interview. While it was hardly akin to the intimacy that can come with months of residence in a small village, one clear strength of this approach was maintaining openness to serendipitous discovery even in a vast urban setting. The fluidity of my approach to the field was right in line with what Amit suggests is the principal asset of ethnography: its malleability and 'the leeway it allows for the ethnographer to respond and adapt flexibly to social circumstances as these arise' (Amit 2000, 10, 16).

THE DIFFICULTIES OF CLASSIFYING OTHERS IN FLEETING URBAN ENCOUNTERS

With such an approach to the urban field, 'categorising' the people I encountered - by ethnicity in particular, but also by many other possible groupings - proved to be virtually impossible. Furthermore, attempting to do so felt unethical. As mentioned, the harsh international review I had received illuminated possible problems and misunderstandings with my use of a category of 'New Zealander' and early in my fieldwork process I attempted to gather an ethnically proportional representation of older New Zealanders. As I moved through my fields of Dunedin and Auckland in the manner described above, open to serendipitous discovery and placing strong significance on passing conversations and participant observation as well as conducting some formal 
interviews, a focus on proportional sampling felt like a regression back to the ossification and essentialisation of fluid and complex categories of social identity - the kind of behaviour that Smith writes has led many Indigenous writers to 'nominate anthropology as representative of all that is truly bad about research' (Smith 1999, 11). While moving through the amorphous urban fields that I have described, trying to single out those who fit particular ethnic categories (particularly Māori or European/Pākehā), I felt not only desperate and vulnerable, but worse, I felt voyeuristic and exploitative. I had to try to judge ethnic identity based on appearances, I had to ask too soon and abruptly, and therefore disrespectfully, a person's ethnic identity to enable me to tick a box. To appease anthropology's lingering requirement to identify different ethnic groups, even if doing so was an attempt to fairly represent the different ethnic identities that fit under the umbrella of 'New Zealander', I was instead perpetuating the violence of singling people out according to their ethnic identities and ascribing labels. I quickly gave up on the idea of a purposive sample that identified the different ethnic categories under the umbrella of 'New Zealander'. Instead, I carried on with my initial approach of using the category of ' $\mathrm{New}$ Zealander' based on nationality and not categorising participants by ethnicity at all. I have come to believe this fit within a cosmopolitan approach to fieldwork methods characterised by consideration of the human 'over and above proximal categorisations and identifications such as nation, ethnicity, class, religion, gender and locale' (Rapport and Stade 2007, 223-4).

\section{COSMOPOLITANISM AS METHOD}

In this section I will briefly introduce cosmopolitanism, particularly discussing cosmopolitanism as method. The concept of cosmopolitanism is itself a 'diversity of related conceptualizations' (Glick-Shiller and Irving 2015, 1) but its roots are typically traced back to the Enlightenment notion that every human has equal worth and ought to have an allegiance to human kind beyond kinship or country (Cheah 2006; Rapport and Stade 2007). The concept's recent resurgence is commonly traced back to Kant's view of a stranger's right not to be treated with hostility (Cheah 2006). Nussbaum (1996) suggested there are certainly different ways of being cosmopolitan, but a shared quality is that of a disposition to openness to the world and its diverse inhabitants (see also Skrbis and Woodward [2013]). However, cosmopolitanism moves beyond individual and collective attitudes and is also routinely used both as a description of the contemporary, globalised world - with its mobility (Sheller and Urry 2006), transnationalism (Glick-Shiller, Basch, and Blanc-Szanton 1992) and superdiversity (Vertovec 2010) - and as an argument for transforming the world into a better one by moving beyond national thinking to a global integration, 
a 'new universalism', and cosmopolitan law (Beck and Sznaider 2006; GlickShiller and Irving 2015; Kahn 2003). Recent approaches to cosmopolitanism have included its manifestation as moral philosophy (Rapport 2012), as ethical project (Appiah 2006), as an argument in support of humanitarianism and an approach to human rights (Tan 2016) and as research methodology as I will discuss here.

Skrbis and Woodward (2013) described what they see as four basic dimensions of cosmopolitanism: cultural, political, ethical and methodological. To become 'methodologically cosmopolitan', they said, is to open up social analysis to the 'relational processes which bind local and global' (Skrbis and Woodward 2013, 3). This 'new type of social analysis' (ibid) is better attuned to investigating contemporary sites of super-diversity or urban multiculturalism. Similarly, Kahn argued that in doing 'anthropology as cosmopolitan practice', anthropologists seek to study a world that is no longer made up of discrete and isolated categories (if it ever was) but instead consists of integrated, cross-cultural relationships (Kahn 2003). However, it is Rapport's (2012) writing on Anyone and cosmopolitan politesse that can be used as a jumping off point for what it might actually look like to enter the field and approach research subjects within a cosmopolitan methodology.

Rapport (2012) wrote that Anyone has the right to be recognised as him/herself and not just as a member of a social category or class. The cosmopolitan project, he said, is to know Anyone in terms of universal human nature and an individual embodiment. A Cosmopolitan Body, he said, certainly practices a particular, localised life, yet it always also embodies global entitlements and universal capacities. Anyone has the freedom to choose a form of life and to form a world-view, but thinking about others in categorical terms 'de-individualises' the person. A cosmopolitan project and approach delegitimises categorical thinking so that the individuality of Anyone is 'never confounded by classificatory, collective identifications or stereotypes' (Rapport 2012, 8). An extremely important part of this, he said, is that public identities and affiliations are and must be voluntary, not ascribed.

Rapport employed the term 'politesse' to describe cosmopolitan 'good manners' that are comprised of 'a polite style of general public exchange and an ethic of individual dignity and freedom' (Rapport 2012, 9). Cosmopolitan politesse is a type of social practice which opposes category thinking (while still recognizing people's intrinsic differences). This approach to other people assures an individual of a space that is not classified - it avoids any presumption of intimacy or close knowledge of another (Stade 2007), such as what category s/ 
he might belong to and what this might mean about her/him. Rapport argued that what appears as superficial polite engagement can be a means to interact with Anyone at a respectful distance, not presuming to know another but recognising Anyone as being on his or her own life course.

This approach to stranger-others might be described by Candea et al. (2015) as a 'productive' type of 'disconnection, distance and detachment' which can be an 'ethical, methodological commitment' (Candea et al. 2015, 1). Candea et al. argued that detachment has taken on various shapes and sizes, some seen as positive, some as negative, throughout history; however, in contemporary social science, detachment has become 'unpalatable' and even 'impossible' as all work seems to focus on degrees of ENgagement rather than disengagement. They suggest this current focus on all things as engagement has come from, in part, the turn in anthropology itself whereby the idea of the 'detached observer' came strongly under attack and anthropologists sought to reframe their own claims to knowledge and to be reflexive about the impact of their own identities upon the research process. With a revived focus on engagement, including the researcher's influential engagement with their research participants, we now miss the ways in which detachment can be an important practice or intention. Detachment can be a dynamic, valued part of social relationships and a productive, deliberate form of ethical engagement (Candea et al. 2015).

This is mirrored in both Wessendorf's (2014) previously mentioned approach to her fieldwork in a London borough as well as in her findings. In her approach to the urban field, Wessendorf often would not have known the categorical associations of her research subjects; her research emphasis was not on categorical experiences but on interactions across difference. Wessendorf (2014) also found that inhabitants of Hackney, London experienced a degree of distance and detachment even as they valued an 'ethos of mixing. She described how private lives in Hackney frequently may not be lived across cultural differences but that this was not perceived as a problem by Hackney residents as long as people adhered to this basic 'ethos of mixing' in shared spaces. In other words, as long as members of different groups interacted, and did so in a civil manner in public spaces, a degree of detachment and distance, a lack of intimate knowledge about the Other, was perfectly acceptable, potentially a form of respect and even functional.

POLITESSE AND A PRODUCTIVE DETACHMENT AS ETHNOGRAPHIC METHOD

In my own exercises of participant observation, I approached others with a methodological 'politesse' similar to that described above by participating in 
something akin to Wessendorf's (2014) urban 'ethos of mixing' characterised by a lack of intimate knowledge. The necessity and ethical nature of this 'detached' approach to participant observation emerges when contrasted to the longer, deeper interactions characteristic of formal interviews. During the course of formal interviews, individuals' categorical identities could often be explored with the appropriate sensitivity given to a person's right to describe their own identity. I was able to proceed with caution and respect, allowing each interviewee the opportunity to specify their ethnic and/or national identity in their own words, typically only asking near the end of the interview when good rapport had been established. The variety of self-identifications that I heard demonstrated the complexity of ethnic and national identities and the total inadequacy of a 'tick box' approach to such categories - particularly when the box is ticked by the anthropologist within the New Zealand context. For example, in response to the question, 'How do you identify yourself?' June (Auckland, age 72) explained,

I always acknowledge my iwi and my hapū and that I am a Māori. Even though I have Scottish ancestry... And somewhere in between there's the stirring up of a Māori potpourri. (Laugh). So I am Māori. And I'm a New Zealander. And uh, this is my heritage, it's my country.

Clare (Auckland, age 70) explained that she could be placed in the Pākehā category, but that she would first describe herself as Kiwi: 'Normally say Kiwi. New Zealander. Kiwi. Pākehā... Just more Kiwi'. Another participant, Fran (Auckland, age 75) told me before the interview began that she was 'half Pākehā and half Māori. When I asked directly at the end of our interview, she responded,

A New Zealander. You know those forms you fill in when you come in off the plane? They haven't got anything in there that says New Zealander. They've got Pākehā, Māori, part-Māori, this that and the[interrupting herself]. I just put down New Zealander.

A moment later she told me again she is half-Māori, half-Pākehā, naming her mother's Iwi and describing her father as 'a white guy'. Grant (Auckland, age 68) demonstrated the true ambiguity that can exist around ethnic identity, for while he had certain labels he was comfortable identifying with, he actually did not know his ethnic heritage,

I'm happy to be called a New Zealander... I mean first, 'New Zealander', second, 'Pākehā New Zealander'. Although, because I was adopted I actually don't know who my father was, so I mean I might 
be...part Māori, I don’t know.

Kate, an older New Zealander I contacted over the phone after meeting her immigrant neighbour, explained her appearance to me so that I would know her when we met up. She said she was, 'Pākehä' and told me what colour bag she would be carrying. Later when we met at the public library, she said, 'I've never used that word before,' meaning 'Pākehä, and said she could not quite explain why she had used it in that moment over the phone. If I had spoken with any of these participants during the insightful but more anonymous and short-lived encounters of participant observation, I could never have asked, guessed nor assigned their ethnic identities in a manner that reflected these complex, nuanced personal descriptions.

All the interviewees were happy to be described as 'New Zealanders' for the purposes of my research and not to the exclusion of other categories. Having this type of conversation about identity, however, in a lengthy interview where rapport had been established, allowed some of the needed time and space to explain individualised and nuanced aspects of their identity, some pertinent to categories often associated with ethnicity. This type of basic respect and sensitivity to personal issues of identity is typically not possible in fleeting, urban contact. Therefore, a respectful distance, of not claiming intimacy and familiarity, of not attempting to categorise, is particularly important in urban fieldwork. In urban settings of diversity, where encounters with difference are a continuous, everyday occurrence, meaningful engagement with the Other is not sustainable as a sole mode of sociality (Glick-Shiller and Irving 2015; Stacey 2015). In fact, Rapport (2012) would argue that maintaining a certain level of superficial engagement in such settings, of polite but distant interaction, is actually an act of respect, allowing individuals to maintain their own identity and life course without presuming to know what those things mean to each person.

In contrast to the interviews described above, where interviewees were afforded some time and space to explain the subtleties of their personal identifications, other more passing interactions required Rapport's (2012) respectful distance. For example, one evening in Auckland I attended a mandolin music group performance. During the intermission, I spoke with an older gentleman, Jim, about the performance and about my research. After the show, when he heard I was catching the bus back to my hotel, he stated, in abrupt hospitality, 'You'll come with us', meaning he and his wife, Janice, would drive me there. In the car, casual and polite conversation easily revealed that Jim and Janice were well over 65 and they had lived their whole lives in Auckland. As we zoomed 
along Auckland's motorway at speed, and then slowed in its clogged inner streets, they told me about the huge amount of change they have seen in their neighbourhood and their city. Janice told me a story about being on a full bus nowadays and occasionally thinking, 'If the driver suddenly said something like, 'Ok, everyone who is not born in New Zealand disappear', then that would leave me and that fellow up there on the bus!' Jim mentioned that he felt he needed to learn to read Chinese so he knew what was inside the various shops. They contrasted this to their memory of the wave of Dutch migrants that came to New Zealand in the 1950 s who were expected to strictly adhere to 'Kiwi norms.' Nowadays', Janice lamented somewhat wistfully, 'you'd struggle to even define what 'normal' is'. As we neared my hotel, Jim and Janice found their way by recalling their student days when they used to navigate this particular part of town, pointing out different buildings that had changed purposes or telling me what 'used to be' on each block. They dropped me at my hotel and I thanked them for the lift and the interesting conversation. They wished me good luck. I never saw them again. I do not know how Janice and Jim would identify themselves in terms of ethnicity or ancestral background.

It would have been completely inappropriate to ask Jim and Janice about their ethnicity during the course of this insightful and relevant, but fleeting, conversation in order to place them into a 'category', particularly if doing so was simply to appease an 'anthropological eye' that too often persists in labelling people too readily in spite of disciplinary discussions about the 'crisis of representation', calls for reflexivity and ample descriptions of all categories as nuanced, fluid and contextual.

\section{CONCLUSION}

Such episodic, occasional, partial and ephemeral social links, between researcher and research subjects, such as my interaction with Jim and Janice, pose particular challenges for ethnographic fieldwork (Amit 2000). And yet, maintaining and cultivating a willingness to seize such unforeseen opportunities when they arise is essential to a living anthropology (Hannerz 2006). In urban ethnography, spontaneous, passing interactions cannot and should not be avoided or eliminated but nor should they be hurriedly categorised by the ethnographer. Anthropologists conducting ethnographic research in diverse settings within New Zealand do so at the periphery of a category-focused 'anthropological gaze'. In diverse, urban settings within Aotearoa New Zealand, I suggest that a cosmopolitan methodology is an appropriate fieldwork method as hurried categorical ascription based on ethnicity is not appropriate or ethical. 
Adopting a cosmopolitan approach by embodying politesse, or a respectful distance, does not and should not entail negating the importance of the categories that hold meaning for people and the categories that people use to identify themselves or others. Nor should a cosmopolitan approach to urban ethnography be a means or justification for skimming over issues of inequality (Valentine 2008). Of course ethnicity and other categories matter. However, the keystone in a cosmopolitan understanding of identity and allegiance is their voluntary nature' (Rapport 2012, 55). Avoiding a hasty assignation of labels and maintaining a productive detachment thereby becomes an ethical duty in spaces of diversity, movement and anonymity. Urban anthropologists, as peripheral strangers amongst strangers, cannot, and should not, claim intimate knowledge through fleeting encounters where labels are somewhat unknown and even arbitrary when the city and its diverse inhabitants are 'the field'.

\section{NOTES}

1 Molly George is a $\mathrm{PhD}$ candidate in the Social Anthropology programme at the University of Otago in Dunedin, New Zealand. She submitted her thesis, 'Ageing in an Increasingly Diverse Aotearoa New Zealand', in mid-2016 and it is currently undergoing review. This doctoral research situated relatively stationary older New Zealanders in the contemporary settings of global movement and difference that have developed around them and presented these older folk as unlikely cosmopolitans in their micro interactions with those now sharing their shops, churches and more. Her research interests include the life course, ageing, cosmopolitanism, multiculturalism, migration and concepts of home. She has worked as a Teaching Fellow for methods and medical anthropology papers in Otago's Department of Anthropology and Archaeology. She has also worked as a Research Fellow in Otago's School of Medicine while conducting ethnographic research with children about playground behaviour and risk.

Email: molly.george@otago.ac.nz

\section{REFERENCES}

Amit, Vered. 200o. 'Introduction'. In Constructing the Field: Ethnographic Fieldwork in the Contemporary World, edited by V. Amit, 1-18. London: Routledge.

Appiah, Anthony. 2006. Cosmopolitanism: Ethics in a World of Strangers. New York: W.W. Norton and Co.

Bartley, Allen, and Paul Spoonley. 2005. Constructing a Workable Multiculturalism in a Bicultural Society. In Waitangi Revisted: Perspectives on the Treaty 
of Waitangi, edited by M. Belgrave, M. Kawharu and D. Williams, 136-148. Auckland: Oxford University Press.

Beck, Ulrich, and N. Sznaider. 2006. 'Unpacking cosmopolitanism for the social sciences: A research agenda'. British Journal of Sociology 57 (1):1-23.

Bishop, Russell. 1998. 'Freeing ourselves from neo-colonial domination in research: A Māori approach to creating knowledge'. International Journal of Qualitative Studies in Education 11 (2):199-219.

Brooking, Tom, and Roberto Rabel. 1995. 'Neither British nor Polynesian: a brief history of New Zealand's other immigrants'. In Immigration and National Identity in New Zealand: One people, Two peoples, Many peoples?, edited by S. Greif, 23-49. Palmerson North: Dunmore Press.

Caldwell, Melissa. 2010. 'Moscow Encounters: Ethnography in a global urban village'. In Urban Life: Readings in the Anthropology of the City, edited by G. Gmelch, R. Kemper and W. Zenner, 55-72. Long Grove, Illinois: Westgate.

Callister, Paul. 2004. 'Seeking an Ethnic Identity: Is "New Zealander" a valid ethnic category?' New Zealand Population Review 30 (1\&2):5-22.

Candea, Matei, Jo Cook, Catherine Trundle, and Thomas Yarrow. 2015. 'Introduction: reconsidering detachment'. In Detachment: Essays on the Limits of Relational Thinking, edited by T. Yarrow, M. Candea, C. Trundle and J. Cook, 1-34. Manchester: Manchester University Press.

Caputo, Virgina. 2000. 'At "home" and "away": reconfiguring the field for late twentieth- century anthropology'. In Constructing the Field: Ethnographic Fieldwork in the Contemporary World, edited by V. Amit-Talai, 19-31. London: Routledge.

Castles, Stephen, and Mark Miller. 2009. The Age of Migration: International Population Movements in the Modern World. Fourth ed. New York: The Guilford Press.

Cheah, Pheng. 2006. 'Cosmopolitanism'. Theory, Culture \& Society 23 (2-3):486496.

D'Alisera, JoAnn. 2004. An Imagined Geography: Sierra Leonean Muslims in America. Philadelphia: University of Pennsylvania Press. 
Drozdzewski, Danielle, and Daniel Robinson. 2015. 'Care-work on fieldwork: taking your own children into the field. Children's Geographies 13 (3):372-378.

Dyck, Noel. 2000. 'Home field advantage?' In Constructing the Field: Ethnographic Fieldwork in the Contemporary World, edited by V. Amit, 32-53. London: Routledge.

Farrelly, Trisia, Rochelle Stewart-Withers, and Kelly Dombrowski. 2014."Being There": mothering and absence/presence in the field'. Sites 11 (2):1-32.

Flinn, Juliana, Leslie B. Marshall, and Jocelyn Armstrong, eds. 1998. Fieldwork and Families: Constructing New Models for Ethnographic Research. Honolulu, HI: University of Hawai'i Press.

Foster, George, and Robert Kemper. 2010. 'Anthropological Fieldwork in Cities'. In Urban Life: Readings in the Anthropology of the City, edited by G. Gmelch, R. Kemper and W. Zenner, 5-19. Long Grove, Illinois: Waveland Press.

Friesen, Wardlow. 2010. 'Auckland: a new wave'. New Zealand Herald, 28 August 2010.

Frohlick, Susan. 2002. "You brought your baby to basecamp?": Families and fieldsites'. The Great Lakes Geographer 9 (1):49-58.

Glick-Shiller, Nina, Linda Basch, and Cristina Blanc-Szanton. 1992. 'Towards a Definition of Transnationalism: Introductory Remarks and Research Questions. In Towards a Transnational Perspective on Migration: Race, Class, Ethnicity and Nationalism Reconsidered, edited by N. Glick-Shiller, L. Basch and C. Blanc-Szanton, i-xiii. New York: New York Academy of Sciences.

Glick-Shiller, Nina, and Andrew Irving. 2015. 'Introduction: What's in a word? What's in a question?' In Whose Cosmopolitanism? Critical Perspectives, Relationalities and Discontents, edited by N. Glick-Shiller and A. Irving, 1-22. New York: Berghahn.

Gmelch, George, and Sharon Bohn Gmelch. 2009. 'Notes From the Field: RuralUrban Difference and Student Fieldwork'. City and Society 21 (2):293-306.

Gottlieb, Alma. 2012. 'Two Visions of Africa: Reflections on Fieldwork in an "Animist Bush" and in an Urban Diaspora'. In The Restless Anthropologist, edited by A. Gottlieb, 81-99. Chicago: University of Chicago Press. 
Hannerz, Ulf. 2006. 'Studying down, up, sideways, through, backward, forwards, away and at home: reflections on the field worries of an expansive discipline'. In Locating the Field: Space, Place and Context in Anthropology, edited by S. Coleman and P. Collins, 23-42. Oxford: Berg.

Hill, Richard S. 2010. 'Fitting multiculturalism into biculturalism: Maori-Pasifika relations in New Zealand from the 1960's'. Ethnohistory 57 (2):291-319.

Huyssen, A, ed. 2008. Other Cities, Other Worlds: Urban Imaginaries in a Globalizing Age. Durham: Duke University Press.

Ingold, Tim. 2014. 'That's enough about ethnography!' Journal of Ethnographic Theory $4(1): 383-395$.

Ip, Manying. 2003. 'Maori-Chinese Encounters: Indigine-immigrant interaction in New Zealand'. Asian Studies Review 27 (2):227-252.

Kahn, Joel. 2003. 'Anthropology as Cosmopolitan Practice?' Anthropological Theory 3 (4): 403-415.

Kukutai, Tahu H., and Robert Didham. 2009. 'In Searth of Ethnic New Zealanders: National naming in the 2006 census'. Social Policy Journal of New Zealand (36): 46-62.

Lochore, R.A. 1951. From Europe to New Zealand: An Account of our Continental European Settlers. Wellington: Reed.

MacPherson, Cluny. 2005. 'Reinventing the nation: building a bicultural future from a monocultural past in Aotearoa/New Zealand'. In Race and Nation: Ethnic Systems in the Modern World, edited by P. Spickard, 215-238. New York: Routledge.

Marotta, Vince. 200o. 'The ambivalence of borders: the bicultural and the multicultural'. In Race, Colour and Identity in Australia and New Zealand, edited by J. Docker and G. Fischer, 178-189. Sydney: University of New South Wales Press.

McMillan, Kate. 2004. 'Developing citizens: subjects, aliens and citizens in New Zealand since 1840'. In Tangata, Tangata: The Changing Ethnic Contours of New Zealand, edited by P. Spoonley, C. MacPherson and D. Pearson, 265-290. Southbank, Victoria: Thomson Dunmore Press. 
Ministry of Social Development. 2010. People [accessed 1 April 2016]. Available from http://socialreport.msd.govt.nz/people/ethnic-composition-population.html.

Monaghan, John, and Peter Just. 200o. Social and Cultural Anthropology: A Very Short Introduction. Oxford: Oxford University Press.

Nussbaum, Martha. 1996. Patriotism and Cosmopolitanism. In For Love of Country, edited by M. Nussbaum and J. Cohen, 3-20. Boston: Beacon Press.

NZPA. 2011. 'Dominion Road identified as Auckland's Chinatown'. New Zealand Herald, June 202011.

Palat, Ravi Arvind. 1996. 'Curries, chopsticks and Kiwis: Asian migration to Aotearoa/New Zealand'. In Nga Patai: Racism and Ethnic Relations in Aotearoa/New Zealand, edited by P. Spoonley, C. MacPherson and D. Pearson, 35-54. Palmerston North: Dunmore Press.

Pardo, Italo, and Giuliana Prato. 2012. 'Introduction: The contemporary significance of anthropology in the city'. In Anthropology in the City, edited by I. Pardo and G. Prato, 1-28. Surrey, England: Ashgate.

Perkinson, Margaret, and Samantha Solimeo. 2013. 'Aging in Cultural Context and as Narrative Process: Conceptual Foundations of the Anthropology of Aging as Reflected in the Works of Margaret Clark and Sharon Kaufman'. The Gerontologist 54 (3):101-107.

Radice, Martha. 2000. Feeling Comfortable: The Urban Experience of Anglo-Montrealers. Saint Nicolas, Quebec: Presses Universite Laval.

Radice, Martha. 2011. 'Ethnography of the street'. Anthropology News 52 (3):13.

Rapport, Nigel. 2012. Anyone: The Cosmopolitan Subject of Anthropology. New York: Berghahn Books.

Rapport, Nigel, and Ronald Stade. 2007. 'A cosmopolitan turn - or return?' Social Anthropology 15 (2):223-35.

Roggeveen, Edward. 1996. 'Dutch Immigrants in New Zealand 1945-1964', MA Thesis, History, University of Auckland, Auckland. 
Sheller, Mimi, and John Urry. 2006. 'The new mobilities paradigm'. Environment and Planning A 38:207-226.

Skrbis, Zlatko, and Ian Woodward. 2013. Cosmopolitanism: Uses of the Idea. Los Angeles: Sage.

Smith, Ian. 2008. 'Maori, Pakeha, Kiwi: Peoples, cultures and sequence in New Zealand archaeology'. In Islands of Inquiry: Colonisation, Seafaring and the Archaeology of Maritime Landscapes, edited by G. Clark, F. Leach and S. O'Connor, 367-380. Canberra: ANu E Press.

Smith, Linda Tuhiwai. 1999. Decolonizing Methodologies: Research and Indigenous Peoples. London: Zed Books Ltd.

Spoonley, Paul. 2011. 'Remaking national identity and citizenship in contemporary Aotearoa/New Zealand'. Paper presented at Interrogating Multiculturalism in Aotearoa New Zealand: an Asian perspective, 19-20 February, Dunedin, New Zealand.

Spoonley, Paul, and Richard Bedford. 2012. Welcome to Our World? Immigration and the Reshaping of New Zealand. Auckland: Dunmore Publishing.

Stacey, Jackie. 2015. 'Whose Cosmopolitanism? The violence of idealizations and the ambivalence of self'. In Whose Cosmopolitanism? Critical perspectives, relationalities and discontents, edited by N. Glick-Shiller and A. Irving, 34-36. New York: Berghahn Books.

Stade, Ronald. 2007. 'Cosmopolitans and cosmopolitanism in anthropology in A Cosmopolitan Turn - or Return?' Social Anthropology 15:223-235.

Statistics New Zealand. 2004. Report of the Review of the Measurement of Ethnicity. Wellington.

Statistics New Zealand. 2014. 2013 Census QuickStats about culture and identity. Wellington.

Stoller, Paul. 2012. 'Afterword'. In The Restless Anthropologist, edited by A. Gottlieb, 159-163. Chicago: University of Chicago Press.

Tan, Lincoln. 2016. 'The Big Read: Why are migrants snubbing NZ's regions?’ New Zealand Herald, 4 January. 
Tolich, Martin. 2002. 'Pakeha "Paralysis": Cultural Safety for Those Researching the General Population of Aotearoa New Zealand'. Social Policy Journal of New Zealand December (19):164-178.

Valentine, Gill. 2008. 'Living with difference: reflections on geographies of encounter'. Progress in Human Geography 32 (2):323-337.

Vertovec, Steven. 2010. 'Super-diversity and its implications'. In Anthropology of Migration and Multiculturalism, edited by S. Vertovec, 65-95. London: Routledge.

Walker, Ranginui. 1985. 'Cultural domination of Taha Maori: The potential for radical transformation' In Political Issues in New Zealand, edited by J. Codd and R. Nash, 73-79. Palmerston North: Dunmore Press.

Ward, Colleen, and En-Yi Lin. 2005. 'Immigration, acculturation and national identity in New Zealand'. In New Zealand Identities: Departures and Destinations, edited by J. Liu, T. McCreanor, T. McIntosh and T. Teaiwa, 155-173. Wellington: Victoria University Press.

Ward, Colleen, and Anne-Marie Masgoret. 2008. 'Attitudes toward immigrants, immigration and multiculturalism in New Zealand: a social psychological analysis'. International Migration Review 42 (1):227-248.

Wessendorf, Susanne. 2014. Commonplace Diversity: Social Relations in a SuperDiverse Context, Global Diversities. London: Palgrave Macmillan UK.

Wilmshurst, Janet, Atholl Anderson, Thomas Higham, and Trevor Worthy. 2008. 'Dating the late prehistoric dispersal of Polynesians to New Zealand using the commensal Pacific rat'. Proceedings of the National Academy of Sciences 105:7676-80.

Zodgekar, Arvind. 2005. "The changing face of New Zealand's population and national identity”. In New Zealand Identities: Departures and Destinations, edited by J. Liu, T. McCreanor, T. McIntosh and T. Teaiwa, 140-154. Wellington: Victoria University Press. 